\title{
Coping with the impacts of urban heat islands. A literature based study on understanding urban heat vulnerability and the need for resilience in cities in a global climate change context
}

\author{
Walter Leal Filho ${ }^{\mathrm{a}}$, Leyre Echevarria Icaza ${ }^{\mathrm{b}}$, Alice Neht ${ }^{\mathrm{c}}$, Maris Klavins ${ }^{\mathrm{d}}$, Edward A. Morgan ${ }^{\mathrm{e}, \mathrm{f}, *}$ \\ ${ }^{a}$ School of Science and the Environment, Manchester Metropolitan University, Chester Street, Manchester M1 5GD, United Kingdom \\ b Department of Architecture, DELFT University of Technology, Delft, The Netherlands \\ ' ISB - Institute of Urban and Transport Planning, RWTH Aachen University, Faculty of Civil Engineering, Mies-van-der-Rohe-Str. 1, 52074 Aachen, Germany \\ ${ }^{d}$ Environmental Science Department, Faculty of Geographical and Earth Sciences, University of Latvia, Raina bulv. 19, Riga LV 1586, Latvia \\ e Cities Research Institute, Griffith University, 170 Kessels Road, Nathan, Brisbane, Queensland 4111, Australia \\ ${ }^{\mathrm{f}}$ Climate Change Response Program, Griffith University, Gold Coast Campus, Parklands Drive, Southport, Queensland 4222, Australia
}

\section{A R T I C L E I N F O}

Article history:

Received 7 March 2017

Received in revised form 22 September 2017

Accepted 9 October 2017

Available online $\mathrm{xxx}$

Keywords:

Urban heat island

Vulnerability

Cities

Climate change

Mitigation

Adaptation

\begin{abstract}
A B S T R A C T
The urban heat island (UHI) is a phenomenon whereby temperature levels in urban areas are higher than in surrounding rural settings. Urban heat islands are a matter of increasing concern, since they can affect communities by exacerbating air pollution and greenhouse gas emissions (due to the greater use of air conditioning) and the occurrence of heat-related illness, and may lead to higher levels of mortality. This paper provides a description of the phenomena of (UHI) and an analysis of how cities are vulnerable to it. It highlights the need for resilience and the variety of means by which the UHI can be tackled. It describes a set of trends in two regions in Germany and Australia, which illustrate the scope of the problem in the northern and southern hemispheres, and the scale of vulnerability. Then, existing UHI vulnerability assessments are analysed to highlight common features and differences. Based on this, we propose a classification of adaptability parameters to support vulnerability assessments. The paper also discusses current mitigation approaches mentioned in the literature, and how these address some vulnerabilities. It concludes that both a better understanding of the UHI phenomena and consideration of the particular context of each city is needed to make urban areas more resilient to UHI.
\end{abstract}

\section{Introduction}

The urban heat island (UHI) effect can be defined as higher temperatures within urban areas compared to their surroundings; however, elevated temperature effects are combined with changes in precipitation patterns, climate extremes as well as impacts of air pollution in urban areas (Oke, 1982; Ward et al., 2016). Differences in solar radiation heating in urban areas is a primary factor increasing the air temperature and surface temperature in urban areas, especially around roads, commercial and industrial territories, if compared with the average temperature of green space and residential areas (Synnefa et al., 2008; Santamouris et al., 2011). The urban heat island effect is a result of growth of urban areas (urbanization), structural and land cover changes, as well as industrialization (Rizwan et al., 2008), created by changes of heat absorbing surfaces, anthropogenic heat production, development of specific air circulation patterns (e.g. street

\footnotetext{
* Corresponding author. Cities Research Institute, Griffith University, 170 Kessels Road, Nathan, Brisbane, Queensland 4111, Australia.

Email addresses: w.leal@mmu.ac.uk (W. Leal Filho); L.EchevarriaIcaza@tudelft. nl (L. Echevarria Icaza); neht@isb.rwth-aachen.de (A. Neht); maris.klavins@lu.lv (M. Klavins); ed.morgan@griffith.edu.au (E.A. Morgan)
}

canyons) and other factors (Stewart and Oke, 2012; Hirano and Yoshida, 2016). The effect is a reality for every urban area independent of its size and geographic location, but for megacities, especially those located in warm climate zones, the manifestation is significantly greater (Stewart and Oke, 2012; Ramamurthy and Sangobanwo, 2016).

The most important negative consequences of UHI are related to increased temperatures in urban territories, and especially higher risks of heat waves and their effects (including increased mortality and morbidity of urban inhabitants), human discomfort, increased energy consumption during summer time (although reduced during winters), impaired air and water quality (Gartland, 2010) and other adverse impacts (Hsieh and Huang, 2016). Heat waves is one of the major risk factors of UHI as they can affect human health resulting in exhaustion, dehydration, circulatory disorders, and potentially death (Gartland, 2010; Wolf et al., 2009; Buchin et al., 2016). Heat waves primarily pose a danger to vulnerable individuals, such as elderly people, the very young, those with social or physical impairments or those unable to afford mitigation measures (such as air conditioning) (Rebetez et al., 2009).

Anthropogenic global warming is likely to be contributing to the increase of UHI effects due to increased average temperatures and 
potentially decreased precipitation, and thus aggravated impacts (Paulina et al., 2015). The summer heat load due to climate change most likely will result in the increase of heat waves in many areas, and they are likely to have higher intensities and longer duration (IPCC, 2013).

Urban heat islands depend not only on the character of physical processes, but also on urban planning approaches (Yang et al., 2016). There exists a strong relationship between the UHI effect and urban configuration (Hsieh et al., 2010). The wind and thermal regime of the cities depends on the land-cover and land-use character of the urban territory (Gago et al., 2013). Urban heat island effect reduction can be achieved as a result of increased evapotranspiration: as the vegetation cover releases latent heat and at the same time reduces the amount of energy available for heating, green areas can potentially cool the surrounding area (Peng et al., 2012; Ali et al., 2016). The natural process of tree transpiration lowers temperature (Gartland, 2010). The green cover of vegetation also reduces the intensity of direct solar exposure and helps to transfer the received solar radiation into latent heat. Water bodies are another feature that can help to reduce thermal load due to a transpiration effect and higher specific heat (Liu and Weng, 2008). The heat island effect can also be reduced by decreasing anthropogenic heat (Emmanuel, 2005).

Strategies of urban heat island mitigation and adaptation through urban planning can be considered as a major tool to achieve adverse impact reduction, especially with regard to the climate change and urban sprawl effects (Gartland, 2010; Stewart and Oke, 2012; Wang et al., 2016). An increase in the percentage of green areas and in the vegetation fraction reduces the thermal pressure that city dwellers face. Thus, urban planners should take into account the impacts of UHI for future cities, and work on the possible solutions to mitigate theme in existing cities (Peng et al., 2012).

This paper uses a literature based study to investigate the nature of the problem and highlight the ever increasing vulnerability of cities to the negative impacts of urban heat. It describes the trends in Germany and Australia, as exemplars of the scope of the problem in the northern and southern hemispheres. Then it discusses and analyses UHI vulnerability assessments found in the literature to highlight common features and differences. It also briefly highlights current mitigation and adaptation options and how they address these vulnerabilities. It concludes that there is a need to better understand the phenomena of UHI and that the context of each city (including its social context) needs to be taken into account to make urban areas more resilient to UHI. We note here that the paper focuses on developed countries for two reasons. Firstly, the majority of the vulnerability conceptualisations analysed are based on cities in developed countries and developed countries have greater ability to adapt. The vulnerability to heat of developing countries is closely tied to socio-economic factors, and addressing these is a far greater priority. To discuss the issue of UHI vulnerability in a developing country context requires a broader discussion of these issues, and we lack the space to do so comprehensively. This is not to suggest UHI is not a factor, and that it should be ignored. The issues and strategies discussed in this paper are still relevant to developing countries, but would need to be adapted to the specific development context.

\section{The vulnerability of cities to climatic change and heat urban effects}

Vulnerability describes physical, social, economic, environmental and institutional structures and processes that determine a system's or object's susceptibility and coping and adaptation capacities regarding the way that it reacts to dangers, such as the effects climatic changes
(Birkmann et al., 2013). Vulnerability is therefore made up of exposure, sensitivity and adaptive capacity (Birkmann, 2008; Bohle and Glade, 2001, 2008; Cardona, 2005; Turner et al., 2003). The IPCC use this three component approach in its reports (IPCC, 2007).

In the context of climate change and UHI, exposure describes to what extent humans, natural assets or material goods are located in places endangered by climatic changes and their consequences. Exposure may be considered directly or indirectly, for example when delimiting study areas for a possible vulnerability analysis. In addition, some approaches use the share of the exposed population or area as a variable for the vulnerability analysis (Birkmann et al., 2012; Turner et al., 2003).

Sensitivity is the degree to which people, natural assets or material goods react to climatic changes and their effects (GTZ, 2004; Riegel et al., 2013). Since a significant change of the exposure would require a change of location, climate change adaptation measures usually aim at reducing sensitivity, i.e. at adapting people, natural assets and material goods to climate change through organizational, structural or other measures (Riegel et al., 2013).

Adaptive capacity describes the ability to handle the negative effects of climatic changes by taking opportunities as they arise and reducing the effects through anticipatory and precautionary action (McGill and Ayyub, 2007). The adaptive capacity depends on factors such as public opinion, political will, and human and financial resources (Riegel et al., 2013). In the context of UHI, this can refer to strategies such as using air-conditioning or irrigated landscaping to cool the areas surrounding neighborhoods and places of residence. It also includes behavioral adaptations, such as spending time indoors during heatwaves or making use of offers of assistance in an emergency (Chow et al., 2012).

Hence a system is vulnerable if it is susceptible to the negative effects of climatic changes and unable to cope with them. Conversely, this means that the vulnerability of a system, region, municipality or household is lower the larger its coping and adaptive capacity is (Smith et al., 2001).

Numerous definitions of 'vulnerability' agree that the term primarily refers to the social or "internal" side of climate impact. This means that the concept of vulnerability provides a counterbalance to the idea that catastrophes and risks are primarily the result of environmental change and natural events. The concept and its application show that not only is the stress of climatic changes or extreme weather events, such as heat stress, responsible for problems and risks, but that the sensitivity, the coping capacity and the adaptive capacity of a society or system influence whether an environmental change or natural event becomes a risk or even a disaster (Birkmann et al., 2013).

In contrast, the "external" side of climate impacts is primarily connected to natural hazards and the direct changes of the climate. However, it must be noted that in natural hazards research, the exposure to climate changes and natural hazards is also partially considered as its own factor that must to some extent be determined independently of vulnerability (UN/ISDR, 2011).

While vulnerability analyses usually focus on environmental disorders on exposed systems and societies, De Graaf et al. (2007: p. $166)$ point out that in practice, "the exposed system may amplify, attenuate, and create stresses and disturbances". There is a relation between human practices and the vulnerability of complex systems such as ecosystems; for example when environmental management practices reduce the coping capacity of ecosystems, making them more vulnerable to external forces like fires and hurricanes (De Graaf et al., 2007; Scheffer et al., 2001). This means that it makes no sense to create a synthetic division between environmental threats and human 
vulnerability. Human and environmental systems are closely linked, and such a distinction prevents a full understanding of the complex interplay between them (De Graaf et al., 2007).

Climate impact research connects the term 'vulnerability' more strongly with aspects of the effects of climatic changes. For example, the IPCC states in its fourth assessment report that the vulnerability depends on the type, extent and speed of the climatic change as well as on the fluctuations that the system is exposed to, its sensitivity regarding these changes and its adaptive capacity (IPCC, 2007a). Accordingly, climate change research focuses intensively on the direct effects of climate change in relation to vulnerability (cf. Zebisch et al., 2005). In the IPCC special report SREX (IPCC, 2012), some integration of the perspectives of natural risk research on the one hand and climate impact research on the other hand has already occurred. It particularly stresses the concept of social vulnerability and makes clear that exposure can also be studied as its own dimension in addition to vulnerability (IPCC, 2012).

Despite the difficulties of developing a shared approach of vulnerability that covers all aspects, the concept of vulnerability with the different research focuses - social, environmental, economic - has contributed significantly to the understanding of climate change as a complex problem of human-environment interaction rather than purely physical events (Birkmann, 2008).

In the risk glossary of United Nations University, Thywissen (2006) states: "vulnerability is a dynamic, intrinsic feature of any community (or household, region, state, infrastructure or any other element at risk) that comprises a multitude of components. The extent to which it is revealed is determined by the severity of the event." Therefore, vulnerability is not a fixed variable, but is influenced by the actions of the people affected. For example, if the hazard potential rises, so does vulnerability; through better prevention of dangers, vulnerability can be reduced (Fleischhauer, 2004).

The future development of vulnerability is particularly important in the context of global warming and UHI. The Intergovernmental Panel on Climate Change (IPCC, 2007) reports that heat waves increased toward the end of the 20th century and are expected to continue to rise in frequency, intensity, and duration on a global scale, which in turn leads is likely to increase heat-related morbidity and mortality as well. Chow et al. (2012: p. 289) note that "maximum temperature is one of the most important components in the physical exposure to heat vulnerability".

The increasing mean temperature is projected to lead to more precipitation in winter but drier summers in many areas, resulting in water resources become more changeable. For example, the Rhine supplies large parts of western Germany and the Netherlands with water relatively consistently, which is largely due to snowmelt from Switzerland usually occurring in June (De Graaf et al., 2007; Ven, 1996). As global warming causes an earlier snowmelt, the water flow becomes less consistent and the chance of water shortages in summer increases (De Graaf et al., 2007).

Cities and urban areas in particular are affected by such developments. Colten (2006) states that the dependency on technological systems and higher population concentrations make cities more vulnerable to the impact of extreme events than rural areas, in which disruptions occur at a much smaller scale.

In 2011, about fifty percent of the world's population lived in urban areas, and according to the OECD this share is increasing yearly and will reach $60 \%$ by 2030 (OECD, 2008; Hallegatte and Corfee-Morlot, 2011). In addition, the urban population in developing countries is expected to grow at roughly twice the rate of that in developed countries from 2005 to 2030 . As they contribute significantly to the national GDP, cities constitute the economic center for most nations.
The high population density coupled with the valuable infrastructure in cities often make them economic, social, and cultural hubs that have disproportionately high impact on the environment, which in turn means they are especially vulnerable to the effects of climate change (Hallegatte and Corfee-Morlot, 2011).

Hallegatte and Corfee-Morlat (2011) list the European heatwave of 2003 as an example of the sorts of extremes that are likely to become more frequent as a result of climate change. Such events have led to a greater awareness of heat-related mortality. Umbrella organizations and international organizations have started providing assistance to cities, and cities are learning from one another and sharing their experiences by providing guides and reports on how to include climate change vulnerability in urban planning (e. Dorld Bank, 2008; UNFCCC, 2009; Hallegatte and Corfee-Morlo, 1).

In cities, the negative health effects of heat waves constitute a significant problem that is only expected to increase with further global warming (Klein Rosenthal et al., 2014; Knowlton et al., 2007). According to Chow et al., "changes in surface conditions accompanying rapid urbanization profoundly changed the local landscape, demography, and ecosystem, with potential consequences for heat vulnerability" (2012: p. 290). Common heat-related causes of death are cardiovascular or respiratory distress (Hallegatte and Corfee-Morlot, 2011; Hoshiko et al., 2010; Klein Rosenthal et al., 2014). Reid et al. (2009: p. 1730) stress that "although understanding vulnerability to heat at the individual biomedical level is important", there are also several factors beyond the individual level, such as place, that "contribute to differing levels of risk" and whose understanding is vital for discovering preventive solutions. Thus, cities should locate vulnerable groups - since not all people are at equal health risk - so as to target their resources as efficiently as possible. This will also enable the development of heat emergency plans (Reid et al., 2009).

Chow et al. (2012: p. 288) identify those "lacking in economic assets and access to public support systems, with diminished physical or cognitive capacities to respond to warnings and missing strong and enduring social support systems" as the groups most vulnerable to hazardous events as they are least able to adapt. For example, in the United States "the capacity to respond to hazards has been linked to racial and ethnic status, income level, gender, age, migration status, and housing tenure" (Chow et al., 2012: p. 288). Including both biomedical and social indicators into their vulnerability assessment of Georgetown County, South Carolina, Cutter et al. (2000) found no overlap between the "areas of the highest biophysical vulnerability" and the "areas of the highest social vulnerability", and concluded that places that "combined medium levels of biophysical vulnerability with medium to high levels of social vulnerability" were the most vulnerable ones (cited in Chow et al., 2012: p. 289). This is in line with several prior smaller studies that linked physical exposure with social vulnerability to heat stress (cf. Harlan et al., 2006), and "socioeconomic status and urban vegetation with heat stress" (Chow et al., 2012: p. 288, referring to Jenerette et al., 2007; cf. also Reid et al., 2009). In Phoenix, Arizona, social inequalities regarding heat exposure are strong:

"Given the importance of irrigated vegetation in UHI mitigation, Jenerette et al. (2007) used a path model to examine social determinants of surface temperature and vegetation patterns: well-off Phoenicians used superior social and economic status to maintain low-density housing units with much irrigated vegetation to reduce heat stress." (Chow et al., 2012: p. 289)

Risk factors for vulnerability to heat stress have been identified by several studies. Vulnerable groups include those over the age of 65, "people with pre-existing cardiovascular and/or respiratory illnesses", 
young children, obese people, and "those using medications that impede thermoregulation" (Klein Rosenthal et al., 2014: p. 45).

According to Hallegatte and Corfee-Morlot (2011), it is vital that local actors understand what future climate change risks their region faces and identify the causes of urban vulnerability. A better understanding of the drivers of climate change impacts is needed for local authorities to effectively communicate with "decision makers, to mobilize political will, to assess adaptation options and to design cost-effective and timely responses" (Hallegatte and Corfee-Morlot, 2011: p. 2). Climate change scientists, impact experts, and local and national decision makers need to communicate in order to generate the foundation of knowledge required for effective adaptation management strategies (Hallegatte and Corfee-Morlot, 2011). This foundation of knowledge must include a clear identification of particularly vulnerable areas (Chow et al., 2012).

With the development of climate adaptation plans, cities can better identify the locations and population groups at greatest risk if they come to a better understanding of "the causes of intra-urban spatial heterogeneity of $[\ldots]$ premature deaths" caused by heat stress (Klein Rosenthal et al., 2014: p. 45). This will also be helpful in the pursuit for adaptable exposures (Klein Rosenthal et al., 2014). Suitable measures can be "policies to improve social cohesion and integration within neighborhoods via widespread dissemination of heat-stress mitigation information" (Chow et al., 2012: p. 300). Since vulnerability varies over space and time and is unequal across different demographic segments, heat mitigation measures have to be tailored to the vulnerable groups (Chow et al., 2012).

In order to deal with uncertainty effectively, it is important to understand the vulnerability of a system, which is not static. A stable, well-functioning system today may become more vulnerable in the future if it fails to adjust to new developments (De Graaf et al., 2007). Cannon et al. (2002) therefore argue that vulnerability assessment must include a predictive quality "and conceptualize what could occur to an identifiable population in case of a future disaster" (De Graaf et al., 2007: p. 166). This means that vulnerability needs to consider to what extent communities and societies are capable of adapting to unclear upcoming developments (De Graaf et al., 2007).

Despite the uncertainty of the exact size and nature of future challenges, solutions must be developed for long time horizons while spatial and financial resources must be set aside to allow for future adaptations (De Graaf et al., 2007). Ideally, such adaptations will not only limit the direct and indirect impacts of climate change, but also come with co-benefits, e.g. by being advantageous for either ecosystem services or energy security and water security (Hallegatte and Corfee-Morlot, 2011).

\section{Methodology: impacts of UHI in cities}

Since the aim of this paper is to help to improve the knowledge basis of urban heat islands and the scale of vulnerability, the methodology used entails a mixed methods approach, which consists of two main components. The first component is a detailed analysis of the literature on the subject issue of urban heat islands, drawing from a variety of international peer reviewed work, case studies and descriptions of trends. This was fed into the first two sections of the paper, which provide a well-founded background description of the problem, outlining its relevance, scope and seriousness to both industrialised and developing countries.

The second component was a review of a variety of measurements used to assess heat vulnerability on the one hand, and the impacts of increased temperatures, also relating to their contribution to the heat island process. The subsequent parts of this paper will therefore han- dle: extreme temperatures in cities, an assessment of urban heat islands vulnerability and a discussion of heat vulnerability indexes.

These form the basis of a set of recommendations made in Section 4, aimed at addressing the problem.

\subsection{Examples of extreme temperatures in cities}

The measurement of UHIs among cities is not an easy undertaking for two main reasons: in temperate climates the numbers of days exceeding $32{ }^{\circ} \mathrm{C}^{1}$ are still rather limited in relation to what is seen in the southern hemisphere. Secondly, the search for the climate data on record needs to zoom in at specific parts of a given city in order to become meaningful. For instance, as shown in Table 1, the numbers of days where temperatures exceeded $32^{\circ} \mathrm{C}$ in the city of Berlin, Germany are between 1 and 13 at Berlin Tegel (the city's central airport), and between 2 and 4 at the Berlin district of Tempelhof, whereas in Hamburg, further to the north, the records show between 1 and 2 days in the same period.

In Australia however, the issue can be seen more clearly. As demonstrated in Table 2, the numbers of day where temperatures exceeding $32{ }^{\circ} \mathrm{C}$ in four Australian cities over an 11 year period is much higher, which demonstrates the seriousness of the problem in the country.

Hence, UHI vulnerability is a serious potential threat. In response, there have been a range of studies looking at how vulnerability to UHI might be assessed. The next section considers these studies, and discussed their strengths and weaknesses.

\subsection{Assessing UHI vulnerability}

In order to be able to produce customised UHI assessments, several studies have attempted to define and map the UHI vulnerability index, which inevitably varies from location to location. The next sections note the different risk factors used for heat exposure, sensitivity and adaptive capacity in the different studies to highlight how different the approaches are. The different approaches are then critically discussed. Table 3 summarizes the variety of factors associated with exposure, sensitivity and adaptation, as well as the variety of tools, for each of the seven vulnerability studies analysed.

Even though the definitions of the parameters associated with exposure, sensitivity and adaptive capacity seem theoretically clear, the reality is that vulnerability studies analysed make different interpretations on the classification of the parameters (Table 3). For example, in the study carried out for London (UK) by Wolf and McGregor (Wolf and McGregor, 2013) (Fig. 1), sensitivity is considered as a consequence of adaptive capacity (which depends on demographics, health status, access to resources, mobility, access to information, access to support and behaviour), and exposure to heat includes outdoor and indoor heat parameters. In contrast, in the study on Australian cities (Loughnan et al., 2013) (Fig. 2) there is greater discrimination between sensitivity and adaptive capacity factors. A study by

\footnotetext{
${ }^{1}$ Defining excessive heat is difficult (Lee, 2014), and a full discussion of suitable measures is beyond the scope of this paper. What is deemed excessive will vary from place to place depending on average temperatures and it has been argued that heat index (temperature and humidity) is a more suitable measure (Robinson, 2001). Also, human thermal comfort has been suggested as a more appropriate indicator in the context of UHI (Coutts et al., 2014). For simplicity, $32{ }^{\circ} \mathrm{C}$ has been chosen here, as it is a figure that has been used in health studies to look at excess deaths due to heat and other health factors (Bi et al., 2011) and several countries use numbers between 30 and 25 to define heatwaves (Lee, 2014). As such it is a simple proxy for a level that begins to create discomfort and significant risks to humans.
} 
Table 1

Number of days with temperatures exceeding $32{ }^{\circ} \mathrm{C}$ in some locations in Germany.

\begin{tabular}{lll}
\hline City & Year & Number of days exceeding $32{ }^{\circ} \mathrm{C}$ \\
\hline Berlin-Tegel & 2011 & 1 \\
Berlin-Tegel & 2012 & 4 \\
Berlin-Tegel & 2013 & 5 \\
Berlin-Tegel & 2014 & 3 \\
Berlin-Tegel & 2015 & 13 \\
Berlin-Tegel & 2016 & 7 \\
Berlin-Tempelhof & 2011 & 2 \\
Berlin-Tempelhof & 2012 & 3 \\
Berlin-Tempelhof & 2013 & 8 \\
Berlin-Tempelhof & 2014 & 5 \\
Berlin-Tempelhof & 2015 & 14 \\
Berlin-Tempelhof & 2016 & 6 \\
Hamburg-Fuhlsbüttel & 2012 & 1 \\
Hamburg-Fuhlsbüttel & 2013 & 1 \\
Hamburg-Fuhlsbüttel & 2015 & 2 \\
\hline
\end{tabular}

Table 2

Frequency and distribution of days with extreme temperatures in Australia. Data from Bureau of Meteorology.

\begin{tabular}{lllll}
\hline & & $\begin{array}{l}\text { Number of days } \\
\text { over } 32^{\circ} \mathrm{C} \text { in } 10 \\
\text { year period }\end{array}$ & $\begin{array}{l}\text { Average annual } \\
\text { number of days } \\
\text { over } 32{ }^{\circ} \mathrm{C}\end{array}$ & $\begin{array}{l}\text { Maximum number } \\
\text { of days over } 32^{\circ} \mathrm{C} \\
\text { in one year }\end{array}$ \\
\hline City & Period & 211 & 19 & $36(2005)$ \\
Brisbane & $2005-2015$ & 211 & 25 & $34(2009)$ \\
Melbourne & $2005-2015$ & 277 & 11 & $15(2015)$ \\
Sydney & $2005-2015$ & 118 & 56 & $74(2011)$ \\
Perth & $2005-2015$ & 622 & & \\
\hline
\end{tabular}

Kozlowski and Yusof (2016) also takes this approach. In a study that was carried out for the cities of Bandar Lampung and Jakarta (Manik and Syaukat, 2015) (Fig. 3), the assessment of the risk factors mainly focused on exposure and sensitivity, leaving adaptive capacity as a virtually a separate study area.

Further the tools used to assess seemingly the same parameter vary from case to case. For example mean air temperature can be measured by retrieving temperatures registered by local urban meteorological stations (which are not that common, as they are typically located outside urban areas precisely to avoid the distortion created by UHI), or by mobile meteorological stations, or using an algorithm to convert land surface temperatures (retrieved from satellite imagery) into air temperatures.

\subsection{Discussion of heat vulnerability indexes}

Going back to the definitions of Section 2 of this study, we could actually say that exposure and sensitivity are given factors, and that the difference compared with adaptability, is that adaptability comprises parameters that can actually be modified and or improved, thus that we can act on. In fact, one of the shortcomings of almost all the analysed articles is that the vulnerability assessment is not necessarily connected to mitigation or remediation actions (i.e. adaptation), and only focuses on mapping the current status quo. Since the definition of vulnerability includes adaptability variables, it would make sense to study and map the adaptability potential of the studied areas when defining vulnerability indexes. We suggest that adaptability potential, could actually be classified on the one hand into short and long term initiatives, and on the other hand into individual and community actions (see Table 4 for examples).

In most of the cases, the UHI vulnerability analysis often concentrates on the short term palliation of the devastating effects of the phenomenon. It is thus important to highlight that in this sense the vulnerability assessment only corresponds to one part of the strategy necessary to adapt our cities to climate change, and often fails to contribute to the long term palliation strategy.

Long term community adaptation guidelines often comprise sustainable urban planning design and implementation measures. The development of UHI resilient urban designs require the overlap of vulnerability assessment maps with existing urban planning regulations, visions and plans for the studied areas (Echevarria Icaza et al., $2016 \mathrm{a}, \mathrm{b}, \mathrm{c})$. The combination between the heat mitigation urban planning proposals and other urban planning priorities should be done using new creative, catalysing and inspiring mapping strategies, capable of ensuring a certain degree of flexibility, to allow the coherence between all the parameters to be taken into consideration (Echevarria Icaza et al., 2016d).

If effective vulnerability mapping and assessment can be achieved, then there is a greater chance that any intervention can be more effective. There are a range of different interventions currently available, as discussed in the next section, and new technologies are likely to improve upon these. However, choosing the right intervention for a particular context is not straightforward, and will need consideration of exposure, vulnerability and adaptive capacity.

\section{Towards mitigating the impacts of urban heat islands}

There have been a range of studies investigating methods to mitigate the UHI effect and a number of recent reviews into mitigation of the UHI effect (Gago et al., 2013; Kleerekoper et al., 2012; Rizwan et al., 2008). Fundamentally, they are based on reducing the air temperature through increasing albedo or increasing evapotranspiration. Hence, they focus on reducing exposure to decrease vulnerability, rather than increasing adaptive capacity or sensitivity. Table 5 summarizes the key methods, which are discussed in more detail in the following sections.

\subsection{Reflective colouring}

The simplest method proposed for mitigating the UHI effect and producing local cooling is based on colouring surfaces to reflect heat (Rosenzweig et al., 2006; Santamouris, 2014; Yang et al., 2015). The UHI is a result of heat being absorbed by the surfaces that dominate the urban environment and then being radiated out. Reflective surfaces are designed to increase the albedo of cities. Instead of absorbing the solar radiation, these surfaces reflect much of it back, thus reducing the localised heating effect. These methods are relatively straightforward and cheap to implement, and can be as simple as painting surfaces, roofs etc. (Yang et al., 2015). However, the mitigation impacts are not always clear. Modelling and empirical studies suggest that reflective surfaces could have significant cooling impact in surfaces, and that this could translate into cooling of several degrees (Yang et al., 2015 and references therein). Furthermore, some studies have noted that reflective surfaces in isolation can actually increase temperatures. Hence, such approaches have to be strategic and relatively wide-spread, as well as highly context specific (Yang et al., 2015). Hence, there is often a requirement to impose rules over roof and wall coverings, which may not always be acceptable. Importantly, such approaches have few other benefits.

\subsection{Urban design}

It has been suggested that urban design and the resulting airflow can exacerbate or mitigate the UHI effect. The types of building, building material used and the morphology of the buildings can all 
Table 3

Summary of literature review on UHI vulnerability index studies.

\begin{tabular}{|c|c|c|c|c|c|}
\hline City/Cities & $\begin{array}{l}\text { Considered risk factors } \\
\text { associated to heat } \\
\text { exposure }\end{array}$ & $\begin{array}{l}\text { Considered risk factors } \\
\text { associated to sensitivity }\end{array}$ & $\begin{array}{l}\text { Considered risk } \\
\text { factors associated } \\
\text { to adaptive } \\
\text { capacity }\end{array}$ & Reference & Tools \\
\hline London, UK & $\begin{array}{l}\text { Living in inner city thus } \\
\text { being exposed to UHI } \\
\text { Thermo isolation of } \\
\text { home (rented tenure) } \\
\text { Living on a high floor of } \\
\text { multi-storey buildings } \\
\text { High Population density } \\
\text { Not having working air } \\
\text { conditioning }\end{array}$ & $\begin{array}{l}\text { Being elderly } \\
\text { Pre-existing illness, } \\
\text { impaired health, including } \\
\text { mental or psychiatric illness } \\
\text { Low economic status, } \\
\text { worker, low education } \\
\text { Living alone, social } \\
\text { isolation } \\
\text { Minority status } \\
\text { Confined to bed, not leaving } \\
\text { home daily } \\
\text { Living in institutions, often } \\
\text { in relation to several of the } \\
\text { above factors }\end{array}$ & $\begin{array}{l}\text { Demographics } \\
\text { health status } \\
\text { access to } \\
\text { resources } \\
\text { mobility } \\
\text { access to } \\
\text { information } \\
\text { access to support } \\
\text { behaviour }\end{array}$ & $\begin{array}{l}\text { Wolf and } \\
\text { McGregor, } \\
2013\end{array}$ & $\begin{array}{l}\text { Satellite imagery retrieved by Modis to map the surface } \\
\text { temperature across the city and GIS to map the municipal data } \\
\text { census (population density, age, illnesses, ethnic group, ...). } \\
\text { A principal component analysis was carried out to explain the } \\
\text { variance by principal component, based on those coefficients, the } \\
\text { special distribution of vulnerability was mapped. }\end{array}$ \\
\hline $\begin{array}{l}\text { New York, } \\
\text { USA }\end{array}$ & $\begin{array}{l}\text { Relative surface } \\
\text { temperature } \\
\text { Proportion of trees }\end{array}$ & $\begin{array}{l}\text { Proportion of homes } \\
\text { receiving public assistance } \\
\text { Proportion of non-hispanic } \\
\text { black residents } \\
\text { Proportion of overall deaths } \\
\text { occurring in the home }\end{array}$ & N/A & $\begin{array}{l}\text { Madrigano } \\
\text { et al., } 2015\end{array}$ & $\begin{array}{l}\text { Meteorological variables of the initial analysis were retrieved } \\
\text { through the data sets from the National Climatic Data Center for } \\
\text { the station of LaGuardia airport (mainly ambient temperature and } \\
\text { relative humidity). Spatial temperature distribution was calculated } \\
\text { using Landsat, and overnight cooling using temperature and land } \\
\text { use regression models. Building density and land-use data were } \\
\text { obtained from the NYC Department of City Planning and } \\
\text { greenery cover were calculated from a Lidar-based classification. } \\
\text { Mortality and neighbourhood data were processed using GIS. } \\
\text { More specifically, mortality data sets were retrieved through the } \\
\text { NYC Department of Health and Mental Hygiene Office of Vital } \\
\text { Statistics, and neighbourhood datasets (socio-economic } \\
\text { characteristics) were obtained through the residential census tract. }\end{array}$ \\
\hline $\begin{array}{l}\text { Australian } \\
\text { Cities }\end{array}$ & $\begin{array}{l}\text { Heat wave characteristics } \\
\text { Strenuous outdoor } \\
\text { activity } \\
\text { Urban Heat Island }\end{array}$ & $\begin{array}{l}\text { Biophysical environment } \\
\text { (Land use; Urban design; } \\
\text { Housing; Accessibility of } \\
\text { health services (number of } \\
\text { aged care facilities and } \\
\text { travelling time from } \\
\text { ambulance depot)) } \\
\text { Socio-demographic factors } \\
\text { (Age; Pre-existing medical } \\
\text { conditions; Socio-economic } \\
\text { status; Isolation; Ethnicity/ } \\
\text { language) }\end{array}$ & $\begin{array}{l}\text { Air conditioning } \\
\text { Heat health plans }\end{array}$ & $\begin{array}{l}\text { Loughnan et } \\
\text { al., } 2013\end{array}$ & $\begin{array}{l}\text { The tools used to assess the spatial distribution of heat were Land } \\
\text { Surface Temperature data obtained with Modis/Terra Land } \\
\text { Surface Temperature and Emissivity Monthly L3 Global satellite } \\
\text { imagery. Greenery assessment was completed using Mesh Block } \\
\text { land use data obtained from Australian Bureau of Statistics. The } \\
\text { rest of municipal datasets were retrieved in GIS. }\end{array}$ \\
\hline $\begin{array}{l}\text { Santiago, } \\
\text { Chile }\end{array}$ & $\begin{array}{l}\text { Land Surface } \\
\text { Temperature }\end{array}$ & $\begin{array}{l}\text { Elderly population } \\
\text { Children } \\
\text { Disabled population } \\
\text { Family structure } \\
\text { Education } \\
\text { Unemployment }\end{array}$ & $\begin{array}{l}\text { Communication } \\
\text { No water supply } \\
\text { Materials } \\
\text { Medical services } \\
\text { Roads } \\
\text { Normalized } \\
\text { Difference } \\
\text { Vegetation Index } \\
\text { (NDVI) }\end{array}$ & $\begin{array}{c}\text { Inostroza et } \\
\text { al., } 2016\end{array}$ & \\
\hline $\begin{array}{l}\text { Amsterdam, } \\
\text { Holland }\end{array}$ & $\begin{array}{l}\text { Land surface temperature } \\
\text { Energy efficiency of } \\
\text { buildings } \\
\text { Imperviousness } \\
\text { Albedo } \\
\text { Normalized Difference } \\
\text { Vegetation Index } \\
\text { (NDVI) } \\
\text { Sky view factor }\end{array}$ & $\begin{array}{l}\text { Spatial distribution of } \\
\text { population } \\
\text { Quality of life. } \\
\text { Age of the population } \\
\text { Spatial distribution of } \\
\text { offices to identify areas with } \\
\text { high electrical consumption } \\
\text { in case of heatwave }\end{array}$ & N/A & $\begin{array}{l}\text { Van der } \\
\text { Hoeven and } \\
\text { Wandl, } \\
2014\end{array}$ & $\begin{array}{l}\text { The tools used to map land surface temperature are Landsat } 5 \\
\text { combined with GIS data. NDVI, albedo and imperviousness were } \\
\text { also obtained through the use of the same satellite dataset } \\
\text { processed with GIS. The sky view factor was obtained using } \\
\text { AHN-2 3D imagery (RWS) processed in GIS. The rest of } \\
\text { parameters were obtained using GIS datasets provided by the } \\
\text { municipalities. }\end{array}$ \\
\hline $\begin{array}{l}\text { Indonesian } \\
\text { Cities }\end{array}$ & $\begin{array}{l}\text { Community knowledge } \\
\text { of climate change } \\
\text { Climate variability }\end{array}$ & $\begin{array}{l}\text { Water availability } \\
\text { Health related to air } \\
\text { temperature } \\
\text { Energy consumption }\end{array}$ & $\begin{array}{l}\text { Social } \\
\text { relationships } \\
\text { Education } \\
\text { Income } \\
\text { House adaptation }\end{array}$ & $\begin{array}{l}\text { Manik and } \\
\text { Syaukat, } \\
2015\end{array}$ & $\begin{array}{l}\text { Depending on the region analysed, the risk factors had different } \\
\text { coefficients. In some areas the exposure parameters had the } \\
\text { greatest influence, in others sensitivity and in others adaptive } \\
\text { capacity. }\end{array}$ \\
\hline
\end{tabular}


Table 3 (Continued)

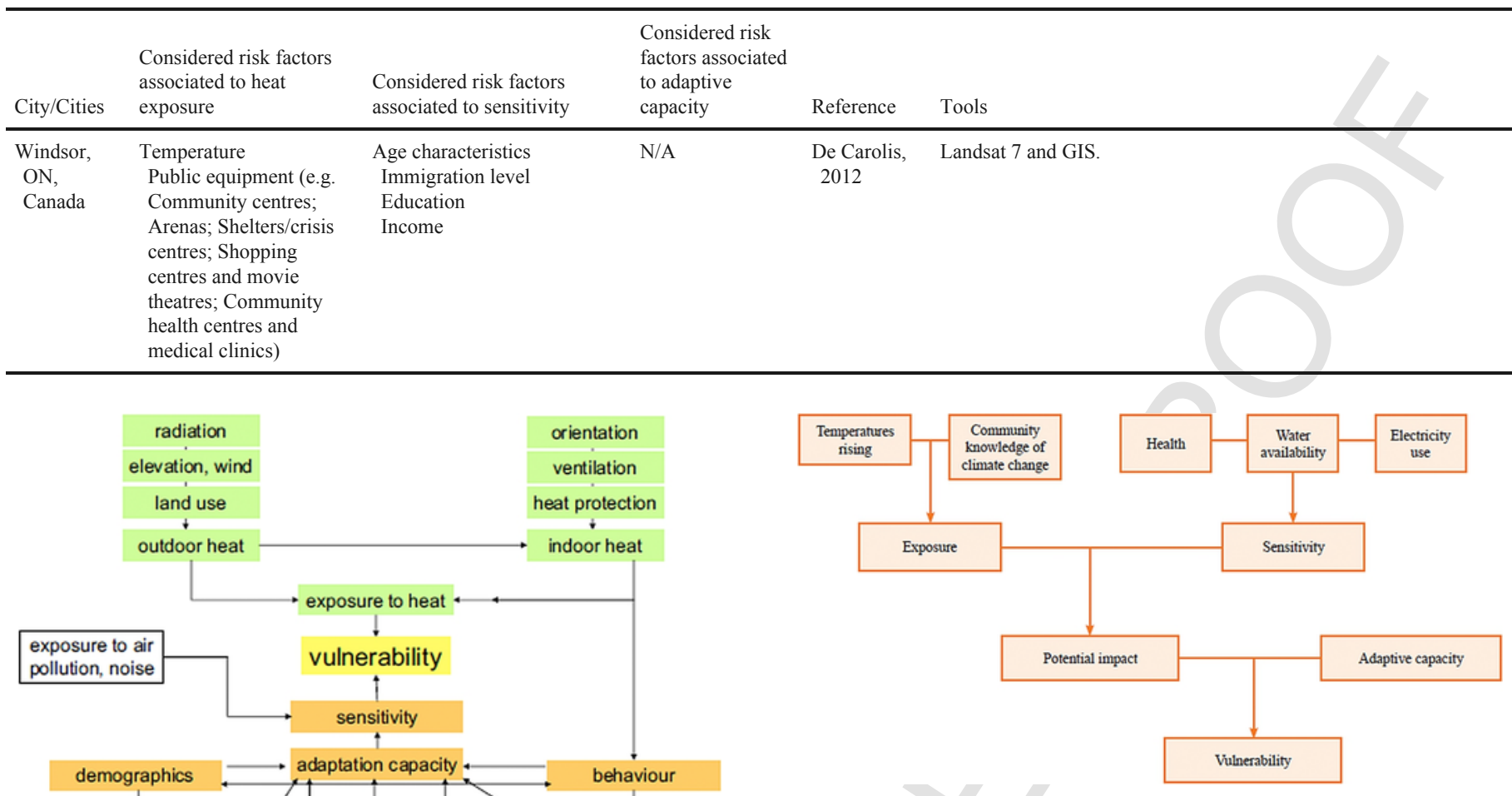

Fig. 3. Framework for index to assess communities' vulnerabilities. Reproduced with permission from: Manik and Syaukat (2015)

Table 4

Examples of classification of adaptability parameters.

Fig. 1. Conceptualisation of heat vulnerability. Reproduced with permission from: Wolf and McGregor (2013).

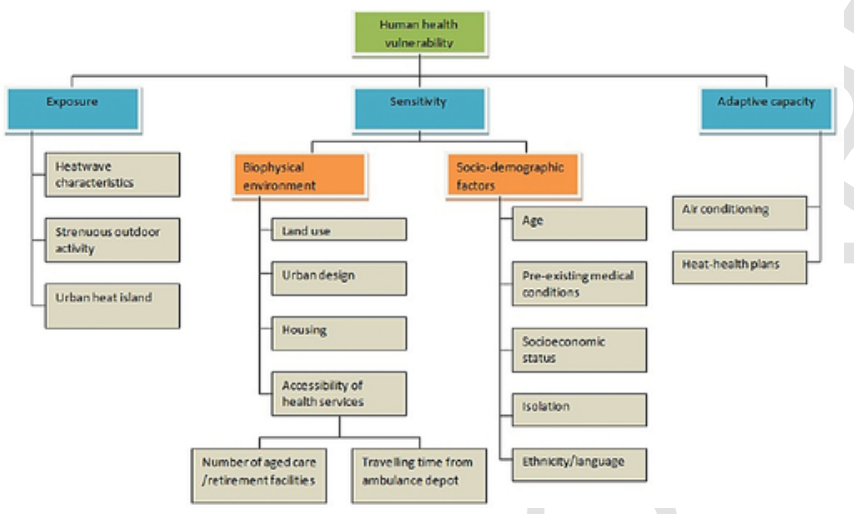

\begin{tabular}{|c|c|c|}
\hline & Short term & Long term \\
\hline Individual & HVAC subsidies & $\begin{array}{l}\text { Education programmes for } \mathrm{UHI} \\
\text { experts training }\end{array}$ \\
\hline Community & $\begin{array}{l}\text { Invite the elderly to spend the day } \\
\text { in cooled public facilities }\end{array}$ & $\begin{array}{l}\text { Resilient urban planning design } \\
\text { and implementation }\end{array}$ \\
\hline
\end{tabular}

Table 5

Methods for mitigating UHI.

\begin{tabular}{|c|c|}
\hline $\begin{array}{l}\text { Mitigation } \\
\text { Method }\end{array}$ & Description \\
\hline $\begin{array}{l}\text { Reflective } \\
\text { Colouring }\end{array}$ & $\begin{array}{l}\text { Use coloured surfaces to reflect heat to increase albedo of cities. } \\
\text { Simple and relatively cheap, but needs widespread and } \\
\text { strategic implementation to be effective }\end{array}$ \\
\hline Urban Design & $\begin{array}{l}\text { Adjusts and improves airflow and building materials to avoid } \\
\text { heating effects. Potentially costly to redesign streets and } \\
\text { requires UHI considerations in planning }\end{array}$ \\
\hline Urban Greening & $\begin{array}{l}\text { Greenery added to urban surfaces cools the surrounding } \\
\text { environment through transpiration. Important to consider type } \\
\text { of vegetation and upkeep. }\end{array}$ \\
\hline Water & $\begin{array}{l}\text { Including water features in urban areas can cool environment } \\
\text { through evapotranspiration. Prone to drought conditions when } \\
\text { UHI is most likely. }\end{array}$ \\
\hline $\begin{array}{l}\text { Green and Blue } \\
\text { Infrastructure }\end{array}$ & $\begin{array}{l}\text { Planned and strategic inclusion of vegetation (green) and water } \\
\text { features (blue) to cool urban areas. Often green and blue } \\
\text { infrastructure can be multi-functional, but requires strategic } \\
\text { planning and design. }\end{array}$ \\
\hline
\end{tabular}

Fig. 2. Factors influencing vulnerability to extreme heat events in Australian cities. Reproduced with permission from: Loughnan et al. (2013).

influence local heating or cooling. It has been suggested that alternative materials such as cool pavements can mitigate the heating effect (Santamouris, 2013). Also, the layout of buildings can create shade and change airflows to help cool urban areas. Ensuring that there are high ratios of street width to street height (Kleerekoper et al., 2012) or ensuring more randomness in the arrangement of taller building (Gago et al., 2013) can reduce the heating effect. Although these approaches imply a more strategic approach, they require substantial intervention by planners and designers. Implementing new materials on

pavements could be costly, and is only really practical as pavements are replaced. Specifying urban form has to take into account a range of factors, not least economic pressures. Adjusting urban form to mit- 
igate the UHI effect is unlikely to be a high priority in urban planning and design.

\subsection{Urban greening: trees, green roofs, green walls, green space}

An alternative to reflective colouring is the use of urban greening (Bowler et al., 2010). Trees and other plants transpire water, which evaporates, resulting in cooling of the surrounding air. At the same time, larger trees create shade resulting in cooler ground areas. Trees have long been identified as a method to cool cities (Lanza and Stone, 2016). More recently, the possibility of green roofs and green walls has been highlighted for their cooling effects (Coutts et al., 2013a; Kolokotsa et al., 2013; Rosenzweig et al., 2006). The cooling effect of large greenspaces, such as parks or urban forests, has also been studied (Feyisa et al., 2014; Gago et al., 2013; Kleerekoper et al., 2012; Rosenzweig et al., 2006).

Although the cooling effects of trees and green areas are well-established there are a number of important considerations for them to be effective. Type of vegetation (Lanza and Stone, 2016) and placing of the greenery is important (Coutts et al., 2013a). Importantly, these urban greening approaches require ongoing maintenance and water and they can become less effective during drought conditions, often when they are most needed (Coutts et al., 2013a, 2014; Kleerekoper et al., 2012). Hence, in areas likely to suffer drought they need to be highly resistant, or replacing them can be very costly. Note, however, that such greenery has a range of multiple benefits, particularly around amenity, water management and energy consumption (Berardi et al., 2014; Bowler et al., 2010; Coutts et al., 2013a; Serrao-Neumann et al., 2015). These not only reduce exposure, but also potentially increase adaptive capacity by improving the neighbourhood in a variety of ways.

\subsection{Water features}

Water features are known to reduce air temperatures around them through evaporation. Thus, urban streams and lakes have the potential to cool urban areas (Coutts et al., 2014; Hathway and Sharples, 2012; Kleerekoper et al., 2012). However, the effects are not straightforward and some studies have suggested that water bodies can actually maintain or increase temperatures at some times during the day (Steeneveld et al., 2014). The latent heat capacity of water maintains a more even temperature and thus diurnal variations are less noticeable. At the same time water features will be prone to drought, which is likely to be when they are most needed (Coutts et al., 2014). However, as with urban greening, water features provide a range of other benefits, such as amenity, and if designed as part of a wider strategy might provide flood mitigation or other benefits (Coutts et al., 2013b, 2014).

\subsection{Green and blue infrastructure}

Building on the possibility of both greenspace and water to provide a cooling effect, strategically planned green areas and water features can be used to mitigate UHI (Gunawardena et al., 2017). This combines the benefits of urban greening and water with the more strategic approach of urban design and planning. The concept of green infrastructure extends beyond a local one-off approach and implies a planned and strategic combination of a range of trees, flora and greenspaces (Matthews et al., 2015). Similarly, blue infrastructure implies the strategic use of water (Hathway and Sharples, 2012). Note that in both cases the infrastructure is designed to perform a range of functions, with cooling being one (Matthews et al., 2015). A more strategic approach can help address some of the issues around one-off interventions, including combining greenspace with water sensitive urban design and ensuring maximum impacts of water and greenery as well as the most efficient use of resources. At the same time, it allows for consideration of trade-offs and multiple benefits in a more strategic approach. Importantly, green and blue infrastructure can make use of existing water features and greenspace, and seek to combine a range of different technologies and interventions. If the multiple benefits of green and blue infrastructure are realised, these not only reduce exposure but also enhance adaptive capacity (through improved spaces) and reduce sensitivity (by improving health).

\section{Conclusions}

This paper has demonstrated that the nature of the problem and the ever increasing vulnerability of cities to the negative impacts of urban heat. Urgent action is needed in order to increase the resilience of urban areas towards the problem.

The literature based study illustrates the scope of the problem, showing that it may be a critical factor for air quality management and public health. What is clear, however, from this analysis is that we need to better understand the phenomena of UHI and how it affects individual cities, and that there is a need to consider mitigation and adaptation strategies which take the particularities of each city into account so as to make them more resilient to UHI. Existing literature presents some of the potential mitigation and adaptation options that are available to designers and planners, including improving open space design, increasing vegetation, greater care with the choice of construction materials in properties, and greater emphasis to urban geometry.

Importantly, however, planners and designers need knowledge and encouragement to take into account the urban island effects, and greater public awareness has to be an important part of adaptation strategies. Choosing the right approach is context-specific and likely to draw on a range of options, including but not limited to infrastructure-based interventions. All these efforts are worthy, since the mitigation of the effects of the urban heat islands is likely to significantly contribute towards enhancing sustainable development at the urban scale.

\section{Uncited references}

Bundesamt für Bevölkerungsschutz und Katastrophenhilfe [BBK], 2010; Gartland, 2008; Lenton, 2013; Riegel, 2005; Serrao-Neumann et al., 2016, IPCC, 2001.

\section{References}

Ali, J.M., Marsh, S.H., Smith, M.J., 2016. Modelling the spatiotemporal change of canopy urban heat islands. Build. Environ. 107, 64-78.

Berardi, U., Ghaffarian Hoseini, A., Ghaffarian Hoseini, A., 2014. State-of-the-art analysis of the environmental benefits of green roofs. Appl. Energy 115, 411-428. https://doi.org/10.1016/j.apenergy.2013.10.047.

Bi, P., Williams, S., Loughnan, M., Lloyd, G., Hansen, A., Kjellstrom, T., Dear, K., Saniotis, A., 2011. The effects of extreme heat on human mortality and morbidity in Australia: implications for public health. Asia-Pacific J. Public Heal 23, 27S-36S. https://doi.org/10.1177/1010539510391644.

Birkmann, J., 2008. Globaler Umweltwandel, Naturgefahren, Vulnerabilität und Katastrophenresilienz. Notwendigkeit der Perspektivenerweiterung in der Raumplanung. Raumforschung und Raumordnung, vol. 66, 5-22, (1).

Birkmann, J., Bach, C., Vollmer, M., 2012. Tools for resilience building and adaptive spatial governance - challenges for spatial and urban planning in dealing with vulnerability. Raumforschung und Raumordnung, vol. 70, 293-308, (4).

Birkmann, J., Böhm, H.R., Buchholz, F., Büscher, D., Daschkeit, A., Ebert, S., Walkenhorst, O., 2013. Glossar Klimawandel und Raumplanung. E-Paper der 
ARL: vol. 10. Hannover second ed., Retrieved from http://nbn-resolving.de/urn: nbn:de:0156-73571.

Vulnerability and criticality. In: Bohle, H.-G., Glade, T. (Eds.), IHDP Newsletter UPDATE 2001(2). Naturrisiken und Sozialkatastrophen, Berlin, Heidelberg, pp. 2001. 435-441, (23.09.2016) http://www.ihdp.uni-bonn.de/html/publications/ publications.html

Bohle, H.-G., Glade, T., 2008. In: Felgentreff, C., Glade, T. (Eds.), Vulnerabilitätskonzepte in Sozial- und Naturwissenschaften. Naturrisiken und Sozialkatastrophen, Berlin, Heidelberg, pp. 435-441.

Bowler, D.E., Buyung-Ali, L., Knight, T.M., Pullin, A.S., 2010. Urban greening to cool towns and cities: a systematic review of the empirical evidence. Landsc. Urban Plan. 97, 147-155. https://doi.org/10.1016/j.landurbplan.2010.05.006.

Buchin, O., Hoelscher, M.T., Meier, F., Nehls, T., Ziegler, F., 2016. Evaluation of the health-risk reduction potential of countermeasures to urban heat islands. Energy Build. 114, 27-37.

Bundesamt für Bevölkerungsschutz und Katastrophenhilfe [BBK], 2010. In: Methode für die Risikoanalyse im Bevölkerungsschutz, Wissenschaftsforum Band 8. Bonn.

Cannon, T., Twigg, J., Rowell, J., 2002. Social Vulnerability, Sustainable Livelihoods and Disasters, Retrieved from http://www.benfieldhrc.org/disaster_studies/ projects/soc_vuln_sust_live.pdf.

Cardona, O.D., 2005. Indicators for Disaster Risk and Risk Management. Program for Latin America and the Caribbean: Summary Report Inter-American Development Bank, Washington.

Chow, W.T.L., Chuang, W.-C., Gober, P., 2012. Vulnerability to extreme heat in metropolitan phoenix: spatial, temporal, and demographic dimensions. Prof. Geogr. 64 (2), 286-302.

Colten, C.E., 2006. Vulnerability and place: flat land and uneven risk in New Orleans. Am. Anthropol. 108 (4), 731-734, Retrieved from http://www.jstor.org/stable/ 4496515.

Coutts, A.M., Daly, E., Beringer, J., Tapper, N.J., 2013a. Assessing practical measures to reduce urban heat: green and cool roofs. Build. Environ. 70, 266-276. https:// doi.org/10.1016/j.buildenv.2013.08.021.

Coutts, A.M., Tapper, N., Beringer, J., Daly, E., White, E., Broadbent, A., Pettigrew, J., Harris, R., Gebert, L., Nice, K., Hamel, P., Fletcher, T., Kalla, M., 2013b. Determine the Microclimate Influence of Harvesting Solutions and Water Sensitive Urban Design at the Micro-scale. Cooperative Research Centre for Water Sensitive Cities, Melbourne.

Coutts, A., Demuzere, M., Tapper, N., Daly, E., Beringer, J., Nury, S., Broadbent, A., Harris, R., Gebert, L., Nice, K., 2014. Impacts of Harvesting Solutions and Water Sensitive Urban Design on Evapotranspiration. Cooperative Research Centre for Water Sensitive Cities, Melbourne.

Coutts, A.M., Loughnan, M., Tapper, N., White, E., Thom, J., Broadbent, A., Harris, R., 2014. Impacts of Water Sensitive Urban Design Solutions on Human Thermal Comfort. Cooperative Research Centre for Water Sensitive Cities, Melbourne.

Cutter, S.L., Mitchell, J.T., Scott, M.S., 2000. Revealing the vulnerability of people and places: a case study of Georgetown County, South Carolina. Ann. Assoc. Am Geogr. 90 (4), 713-737.

De Carolis, L., 2012. The Urban Heat Island Effect in Windsor, ON: an Assessment of Vulnerability and Mitigation Strategies (Report Prepared for the City of Windsor)

De Graaf, R.E., van de Giesen, N.C., van de Ven, F.H.M., 2007. The closed city as a strategy to reduce vulnerability of urban areas for climate change. Water Sci. Technol. a J. Int. Assoc. Water Pollut. Res. 56 (4), 165-173. https://doi.org/10. 2166/wst.2007.548.

Echevarria מחمמא L., van der Hoeven, F., van den Dobbelsteen, 2016 b. A. Surface therma sis of North Brabant cities and neighborhoods during heat waves. TeMA 1 . Eurld Use Mobil. Environ. 9, https://doi.org/10.6092/1970-9870/3741, (in press).

Echevarria Icaza, L., van den Dobbelsteen, A., van der Hoeven, F., 2016 c. The urban heat island effect in Dutch City centers: identifying relevant indicators and first explorations. In: Leal Filho, W., Adamson, K., Dunk, R., Azeiteiro, U.M., Illingworth, S., Alves, F. (Eds.), Implementing Climate Change Adaptation in Cities and Communities. Springer International Publishing AG, Cham, Switzerland, 2016.

Echevarría Icaza, L., van den Dobbelsteen, A., van der Hoeven, F., 2016 d. Integrating urban heat assessment in urban plans. Sustainability 2016 (8), 320

Echevarria Icaza, L., van den Dobbelsteen, A., van der Hoeven, F., 2016a. Using satellite imagery analysis to redesign provincial parks for a better cooling effect on cities. The case study of South Holland. In: Research in Urbanism Series IV. TU Delft, Delft, The Netherlands.

Emmanuel, M.R., 2005. An Urban Approach to Climate-sensitive Design Strategies for the Tropics. Taylor \& Francis.

Feyisa, G.L., Dons, K., Meilby, H., 2014. Efficiency of parks in mitigating urban heat island effect: an example from addis ababa. Landsc. Urban Plan. 123, 87-95. https: //doi.org/10.1016/j.landurbplan.2013.12.008.

Fleischhauer, M., 2004. Klimawandel, Naturgefahren und Raumplanung (Ziel- und Indikatorenkonzept zur Operationalisierung räumlicher Risiken. Dortmund).
Gago, E.J., Roldan, J., Pacheco-Torres, R., Ordóñez, J., 2013. The city and urban heat islands: a review of strategies to mitigate adverse effects. Renew. Sustain. Energy Rev. 25, 749-758. https://doi.org/10.1016/j.rser.2013.05.057.

Gartland, L., 2008. Heat Islands: Understanding and Mitigating Heat in Urban Areas. Earthscan.

Gartland, L., 2010. Heat Islands: Understanding and Mitigating Heat in Urban Areas. Routledge, London.

Deutsche Gesellschaft für Technische Zusammenarbeit GmbH [GTZ], 2004. Risikoanalyse - eine Grundlage der Katastrophenvorsorge (Handreichung im Auftrag des Bundesministeriums für wirtschaftliche Zusammenarbeit und Entwicklung. Eschborn).

Gunawardena, K.R., Wells, M.J., Kershaw, T., 2017. Utilising green and bluespace to mitigate urban heat island intensity. Sci. Total Environ. 1-16. https://doi.org/10. 1016/j.scitotenv.2017.01.158

Hallegatte, S., Corfee-Morlot, J., 2011. Understanding climate change impacts, vulnerability and ada-ptation at city scale: an introduction. Clim. Change 104 (1), 1-12. https://doi.org/10.1007/s10584-010-9981-8.

Harlan, S.L., Brazel, A.J., Prashad, L., Stefanov, W.L., Larsen, L., 2006. Neighborhood microclimates and vulnerability to heat stress. Soc. Sci. Med. 63, 2847-2863.

Hathway, E.A., Sharples, S., 2012. The interaction of rivers and urban form in mitigating the Urban Heat Island effect: a UK case study. Build. Environ. 58, 14-22. https://doi.org/10.1016/j.buildenv.2012.06.013.

Hirano, Y., Yoshida, Y., 2016. Assessing the effects of $\mathrm{CO}_{2}$ reduction strategies on heat islands in urban areas. Sust. Cities Soc. 26, 383-392.

Hoshiko, S., English, P., Smith, D., Trent, R., 2010. A simple method for estimating excess mortality due to heat waves, as applied to the 2006 California heat wave. Int. J. Public Health 55, 133-137.

Hsieh, C.M., Huang, H.C., 2016. Mitigating urban heat islands: a method to identify potential wind corridor for cooling and ventilation. Comp. Environ. Urban Syst. 57, 130-143.

Hsieh, C.-M., Chen, H., Ooka, R., Yoon, J., Kato, S., Miisho, K., 2010. Simulation analysis of site design and layout planning tomitigate thermal environment of riverside residential development. Build. Simul. 3 (1), 51-61.

Inostroza, L., Palme, M., de la Barrera, F., 2016. A heat vulnerability index: spatial patterns of exposure, sensitivity and adaptive capacity for Santiago de Chile. PLoS ONE 11 (9), e0162464. https://doi.org/10.1371/journal.pone.0162464.

IPCC [Intergovernmental Panel on Climate Change], 2001. Impacts, Adaptation, and Vulnerability for Climate Change, Third Assessment Report of the IPCC. Cambridge University Press, Cambridge, UK.

IPCC, 2007. Climate Change Glossary: Contribution of Working Group II to the Fourth Assessment Report of the Intergovernmental Panel on Climate Change. Cambridge University Press, Cambridge, UK.

IPCC, 2007a. Climate Change 2007. Impacts, Adaptation and Vulnerability (Contribution of Working Group II to the Fourth Assessment Report of the IPCC. Cambridge).

IPCC, 2012. Managing the Risks of Extreme Events and Disasters to Advance Climate Change Adaptation. Special Report Cambridge University Press, Cambridge, UK.

IPCC, 2013. Summary for policymakers. In: Stocker, T.F., Qin, D., Plattner, G.-K. Tignor, M., Allen, S.K., Boschung, J., Nauels, A., Xia, Y., Bex, V., Midgley, P.M. (Eds.), Climate Change 2013: the Physical Science Basis. Cambridge University Press, Cambridge, UK.

Jenerette, G.D., Harlan, S.L., Brazel, A., Jones, N., Larsen, L., Stefanov, W.L., 2007. Regional relationships between surface temperature, vegetation, and human settlement in a rapidly urbanizing ecosystem. Landsc. Ecol. 22, 353-365.

Kleerekoper, L., Van Esch, M., Salcedo, T.B., 2012. How to make a city climate-proof, addressing the urban heat island effect. Resour. Conserv. Recycl. 64, 30-38. https://doi.org/10.1016/j.resconrec.2011.06.004.

Klein Rosenthal, J., Kinney, P.L., Metzger, K.B., 2014. Intra-urban vulnerability to heat-related mortality in New York City, 1997-2006. Health \& place 30, 45-60. https://doi.org/10.1016/j.healthplace.2014.07.014.

Knowlton, K., Lynn, B., Goldberg, R.A., Rosenzweig, C., Hogrefe, C., Rosenthal, J.K., Kinney, P.L., 2007. Projecting heat-related mortality impacts under a changing climate in the New York City region. Am. J. Public Health 97, 2028-2034.

Kolokotsa, D., Santamouris, M., Zerefos, S.C., 2013. Green and cool roofs' urban heat island mitigation potential in European climates for office buildings under free floating conditions. Sol. Energy 95, 118-130. https://doi.org/10.1016/j.solener. 2013.06.001.

Kozlowski, M., Yusof, Y.M., 2016. The role of urban planning and design in responding to climate change: the Brisbane experience. Int. J. Clim. Change Strategies Manag. 8 (1), 80-95.

Lanza, K., Stone, B., 2016. Climate adaptation in cities: what trees are suitable for urban heat management?. Landsc. Urban Plan. 153, 74-82. https://doi.org/10.1016/j. landurbplan.2015.12.002.

Lee, W.V., 2014. Historical global analysis of occurrences and human casualty of extreme temperature events (ETEs). Nat. Hazards 70, 1453-1505. https://doi.org/10. 1007/s11069-013-0884-7. 
Lenton, T.M., 2013. Environmental tipping points. Annu. Rev. Environ. Resour. https: //doi.org/10.1146/annurev-environ-102511-084654.

Liu, H., Weng, Q., 2008. Seasonal variations in the relationship between landscape pattern and land surface temperature in Indianapolis, USA. Environ. Monit. Assess. 144, 199-219.

Loughnan, M.E., Tapper, N.J., Phan, T., Lynch, K., McInnes, J.A., 2013. A Spatial Vulnerability Analysis of Urban Populations during Extreme Heat Events in Australian Capital Cities. National Climate Change Adaptation Research Facility, Gold Coast 128.

Madrigano, J., Ito, K., Johnson, S., Kinney, P.L., Matte, T., 2015. A case-only study of vulnerability to heat wave-related mortality in New York City (2000-2011). Environ. Health Perspect. 123, 672-678. https://doi.org/10.1289/ehp.1408178.

Manik, T.K., Syaukat, S., 2015. The Impact of Urban Heat Islands: Assessing Vulnerability in Indonesia. Asian Cities Climate Resilience Working Paper Series 2015, 13.

Matthews, T., Lo, A.Y., Byrne, J.A., 2015. Reconceptualizing green infrastructure for climate change adaptation: barriers to adoption and drivers for uptake by spatial planners. Landsc. Urban Plan. 138, 155-163. https://doi.org/10.1016/j.landurbplan. 2015.02.010.

McGill, W.L., Ayyub, B.M., 2007. The meaning of vulnerability in the context of critical infrastructure protection. In: Critical Infrastructure Protection. Elements of Risk. Critical Infrastructure Protection Program. George Mason University - Center for Infrastructure Protection, pp. 25-48.

OECD [Organization for Economic Cooperation and Development], 2008. OECD Environmental Outlook to 2030. OECD, Paris.

Oke, T.R., 1982. The energetic basis of the urban heat island. Q. J. R. Meteorol. Soc. $108,1-24$.

Paulina, W., Chin, L.P., Melissa, H., 2015. Temporal statistical analysis of urban heat islands at the microclimate level. Proc. Environ. Sci. 26, 91-94.

Peng, S., Piao, S., Ciais, P., Friedlingstein, P., Ottle, C., Bréon, F.-M., Nan, H., Zhou, L., Myneni, R.B., 2012. Surface urban heat island across 419 global big cities. Environ. Sci. Technol. 46, 696-703.

Ramamurthy, P., Sangobanwo, M., 2016. Inter-annual variability in urban heat island intensity over 10 major cities in the United States. Sust. Cities Soc. 26, 65-75.

Rebetez, M., Dupont, O., Giroud, M., 2009. An analysis of the July 2006 heatwave extent in Europe compared to the record year of 2003. Theor. Appl. Climatol. 95, $1-7$.

Reid, C.R., O’Neil, M.S., Gronlund, C.J., Brines, S.J., Brown, D.G., Diez-Roux, A.V., Schwartz, J., 2009. Mapping community determinants of heat vulnerability. Environ. Health Perspect. 117 (11), 1730. https://doi.org/10.1289/ehp.0900683.

Riegel, C., 2005. Verwundbarkeit von Gemeinden: Kommunale Risikomanagementkonzepte in Deutschland und Guatemala (Diplomarbeit an der Fakultät Raumplanung der Universität Dortmund).

Riegel, C., Trum, A., Maximini, C., Vallée, D., 2013. Klimaschutzteilkonzept "Anpassung an den Klimawandel für die Städte Solingen und Remscheid, Aachen. Retrieved from http://www.bergischesdreieck.de/fileadmin/user_upload/ wirtschaftsregion/PDFs/Regionales_Klimaschutzteilkonzept_Klimawandel.pdf. pdf.

Rizwan, A.M., Dennis, L.Y.C., Liu, C., 2008. A review on the generation, determination and mitigation of Urban Heat Island. J. Environ. Sci. 20, 120-128. https://doi. org/10.1016/S1001-0742(08)60019-4.

Robinson, P.J., 2001. On the definition of a heat wave. J. Appl. Meteorol. 40, 762-775. https://doi.org/10.1175/1520-0450(2001)040.

Rosenzweig, C., Solecki, W., Slosberg, R., 2006. Mitigating New York City's heat island with urban forestry, living roofs, and light surfaces. In: 86th AMS Annu. Meet. p. 5.

Santamouris, M., 2013. Using cool pavements as a mitigation strategy to fight urban heat island - a review of the actual developments. Renew. Sustain. Energy Rev. 26, 224-240. https://doi.org/10.1016/j.rser.2013.05.047.

Santamouris, M., 2014. Cooling the cities - a review of reflective and green roof mitigation technologies to fight heat island and improve comfort in urban environments. Sol. Energy 103, 682-703. https://doi.org/10.1016/j.solener.2012.07.003.
Santamouris, M., Synnefa, A., Karlessi, T., 2011. Using advanced cool materials in the urban built environment to mitigate heat islands and improve thermal comfort conditions. Sol. Energy 85 (12), 3085-3102.

Scheffer, M., Carpenter, S., Foley, J.A., Folke, C., Walker, B., 2001. Catastrophic shifts in ecosystems. Nature 413, 591-596.

Serrao-Neumann, S., Schuch, G., Taygfeld, P., Renouf, M., Kenway, S.J., Low Choy, D., 2015. Essential Components of an Integrated Greenspace Framework. Linking the city to its regional catchments Cooperative Research Centre for Water Sensitive Cities, Melbourne.

Serrao-Neumann, S., Davidson, J.L., Baldwin, C.L., Dedekorkut-Howes, A., Ellison, J.C., Holbrook, N.J., Howes, M., Jacobson, C., Morgan, E.A., 2016. Marine governance to avoid tipping points: can we adapt the adaptability envelope?. Mar. Policy 65, 56-67. https://doi.org/10.1016/j.marpol.2015.12.007.

Smith, J.B., Schellnhuber, H.J., Qader Mirza, M.M., 2001. Vulnerability to climate change and reasons for concern: a synthesis. In: McCarthy, J.J., Canziani, O.F., Leary, N.A., Dokken, D.J., White, K. (Eds.), Climate Change 2001. Impacts, Adaptation and Vulnerability. Cambridge. pp. 913-967.

Steeneveld, G.J., Koopmans, S., Heusinkveld, B.G., Theeuwes, N.E., 2014. Refreshing the role of open water surfaces on mitigating the maximum urban heat island effect. Landsc. Urban Plan. 121, 92-96. https://doi.org/10.1016/j.landurbplan.2013. 09.001.

Stewart, I.D., Oke, T.R., 2012. Local climate zones for urban temperature studies. Bull.Am.Meteorol. Soc. 93, 1879-1900.

Synnefa, A., Dandou, A., Santamouris, M., Tombrou, M., Soulakellis, N., 2008. On the use of cool materials as a heat island mitigation strategy. J. Appl. Meteorol. Climatol. 47 (11), 2846-2856.

Thywissen, K., 2006. Components of Risk: a Comparative Glossary. UNU-EHS No. 2.2006. Bonn Germany.

Turner, B.L., Kasperson, R.E., Matson, P.A., McCarthy, J.J., Corell, R.W., Christensen, L., Eckley, N., Kasperson, J.X., Luers, A., Martello, M.L., Polsky, C., Pulsipher, A., Schiller, A., 2003. A framework for vulnerability analysis in sustainability science. Proc. Natl. Acad. Sci. U. S. A. 100 (14), 8074-8079.

UN/ISDR [United Nations International Strategy for Disaster Reduction], 2011. Global Assessment Report in Disaster Risk Reduction 2011: Revealing Risk, Redefining Development, (22.09.2016) http://www.preventionweb.net/english/hyogo/gar/ 2011/en/home/index.html.

Van der Hoeven, F., Wandl, A., 2014. Amsterwarm: mapping the landuse, health and energy-effic mplications of the Amsterdam urban heat island. Build. Serv. Eng. Res. T

Ven, G.P., 1996. Man Made Lowlands. History of Water Management and Land Reclamation in the Netherlands (Matrijs, Utrecht, The Netherlands).

Wang, J., Huang, B., Fu, D., Atkinson, P.M., Zhang, X., 2016. Response of urban heat island to future urban expansion over the Beijing-Tianjin-Hebei metropolitan area. Appl. Geogr. 26-36.

Ward, K., Lauf, S., Kleinschmit, B., Endlicher, W., 2016. Heat waves and urban heat islands in Europe: a review of relevant drivers. Sci. Total Environ. 569-570, $527-539$.

Wolf, T., McGregor, G., 2013. The development of a heat wave vulnerability index for London, United Kingdom. Weather Clim. Extrem. 1, 59-68.

Wolf, T., Mcgregor, G., Analitis, A., 2009. Assessing vulnerability to heat stress in urban areas. The example of greater London. Epidemiology 20, S24. https://doi.org/ 10.1097/01.ede.0000362249.11577.19.

Yang, J., Wang, Z.H., Kaloush, K.E., 2015. Environmental impacts of reflective materials: is high albedo a "silver bullet" for mitigating urban heat island?. Renew. Sustain. Energy Rev. 47, 830-843. https://doi.org/10.1016/j.rser.2015.03.092.

Yang, J., Wang, Z.H., Kaloush, K.E., Dylla, H., 2016. Effect of pavement thermal properties on mitigating urban heat islands: a multi-scale modeling case study in Phoenix. Build. Environ. 108, 110-121.

Zebisch, M., Grothmann, T., Schröter, D., Haße, C., Fritsch, U., Cramer, W., 2005. Klimawandel und Klimaanpassung in Deutschland (Vulnerabilität klimasensitiver Systeme. Potsdam, Dessau). 